Table 1.

\begin{tabular}{|c|c|c|c|}
\hline \multirow{2}{*}{$\begin{array}{l}\text { Dependent variables } \\
\text { US_SEScore }\end{array}$} & \multirow{2}{*}{$\begin{array}{c}\text { Study Population } \\
\text { RA }\end{array}$} & \multicolumn{2}{|c|}{$p$ values } \\
\hline & & PSA OLIGO & .021 \\
\hline & & PSA POLY & .356 \\
\hline & PSA & RA & .021 \\
\hline & OLIGO & PSA POLY & .014 \\
\hline & PSA & RA & .356 \\
\hline & POLY & PSA OLIGO & .014 \\
\hline \multirow[t]{6}{*}{ US_SHScore } & RA & PSA OLIGO & .001 \\
\hline & & PSA POLY & .336 \\
\hline & PSA & $\mathrm{RA}$ & .001 \\
\hline & OLIGO & PSA POLY & .004 \\
\hline & PSA & RA & .336 \\
\hline & POLY & PSA OLIGO & .004 \\
\hline \multirow[t]{6}{*}{ US_PDScore } & RA & PSA OLIGO & .011 \\
\hline & & PSA POLY & .102 \\
\hline & PSA & RA & .011 \\
\hline & OLIGO & PSA POLY & .006 \\
\hline & PSA POLY & RA & .102 \\
\hline & & PSA OLIGO & .006 \\
\hline \multirow[t]{6}{*}{ US_MCP2Score } & RA & PSA OLIGO & .000 \\
\hline & & PSA POLY & .276 \\
\hline & PSA & RA & .000 \\
\hline & OLIGO & PSA POLY & .002 \\
\hline & PSA POLY & RA & .276 \\
\hline & & PSA OLIGO & .002 \\
\hline \multirow[t]{6}{*}{ US_WRISTScore } & RA & PSA OLIGO & .032 \\
\hline & & PSA POLY & .610 \\
\hline & PSA & RA & .032 \\
\hline & OLIGO & PSA POLY & .047 \\
\hline & PSA POLY & RA & .610 \\
\hline & & PSA OLIGO & .047 \\
\hline \multirow[t]{6}{*}{ US_KNEEScore } & RA & PSA OLIGO & 1.000 \\
\hline & & PSA POLY & .133 \\
\hline & PSA OLIGO & RA & 1.000 \\
\hline & & PSA POLY & .180 \\
\hline & PSA POLY & RA & .133 \\
\hline & & PSA OLIGO & .180 \\
\hline \multirow[t]{6}{*}{ US_KNEEScore } & RA & PSA OLIGO & 1.000 \\
\hline & & PSA POLY & .133 \\
\hline & PSA & RA & 1.000 \\
\hline & OLIGO & PSA POLY & .180 \\
\hline & PSA POLY & RA & .133 \\
\hline & & PSA OLIGO & .180 \\
\hline
\end{tabular}

US: ultrasound; SE synovial effusion; SH synovial hypertrophy;

PD power Doppler; MCP metacarpophalangeal; PSA psoriatic arthritis;

OLIGO oligoarticular; POLYpolyarticular

therefore a complementary tool to the clinic, fast and well integrated into the overall assessment of the arthritic patient.

References:

[1] Zabotti A. et al. Clin Exp Rheumatol. 2018; 36:519-525.

[2] Perricone C et al. Rheumatology (Oxford) 2012; 51:866-73.

Disclosure of Interests: Fabiana Figus: None declared, Luca Idolazzi: None declared, Porin Perić: None declared, Alen Zabotti Speakers bureau: Celgene, Janssen, Ilaria Tinazzi: None declared, Irene Azzolin: None declared, ERIKA MONTABONE: None declared, Tanya Sapundzhieva: None declared, Anastas Batalov: None declared, PLAMEN TODOROV: None declared, Rositsa Karalilova: None declared, Annamaria lagnocco Grant/research support from: Abbvie, MSD and Alfasigma, Consultant of: AbbVie, Abiogen, Alfasigma, Biogen, BMS, Celgene, Eli-Lilly, Janssen, MSD, Novartis, Sanofi and Sanofi Genzyme, Speakers bureau: AbbVie, Alfasigma, BMS, Eli-Lilly, Janssen, MSD, Novartis, Sanofi DOI: 10.1136/annrheumdis-2020-eular.6394

\section{AB0766 \\ ACCURACY OF PATIENT REPORTED OUTCOME REPORTING IN RANDOMIZED CONTROLLED TRIALS IN PSORIATIC ARTHRITIS}

B. Frade-Sosa ${ }^{1,2,2}$, A. Kerschbaumer ${ }^{2}$, P. Studenic ${ }^{2}$, E. Chwala ${ }^{3}$, J. S. Smolen ${ }^{2}$, D. Aletaha ${ }^{2} .{ }^{1}$ Hospital Clinic, Rheumatology, Barcelona, Spain; ${ }^{2}$ Medical University of Vienna, Internal Medicine III, Division of Rheumatology, Vienna, Austria; ${ }^{3}$ Medical University of Vienna, University Library, Vienna, Austria

Background: Patient-reported outcomes (PROs) allow incorporating the patient's perspective and health related quality of life (HRQoL) into shared decision making when choosing the optimal treatment strategy in patients suffering from psoriatic arthritis (PsA). PsA is a chronic inflammatory disease with heterogeneous manifestations with a range of symptoms, co-morbidities and reduced quality of life. International working groups (1) emphasized to integrate these outcomes as endpoints in clinical trials and as part of the core set of measures. Objectives: To evaluate the quality of PRO reporting in randomized clinical trials in PsA.
Methods: We conducted a systematic literature review (PROSPERO ID 160930) searching PUBMED, MEDLINE and the Cochrane Library for publications (in English language) on randomized controlled trials investigating biological or targeted synthetic disease modifying drugs in adult PsA patients that included some PROs to evaluate the response to treatment. Two of the authors (BFS, AK) screened, selected and extracted the data of the trials that fulfilled inclusion criteria. Statistics were descriptive.

Results: Of 1392 articles in total 880 were screened (512 duplicates); 92 were selected for detailed analysis with 48 finally analysed. $87 \%$ were primary publications were some patient-outcome measure were reported. The Health Assessment Questionnaire Disability Index (HAQ-DI) was reported in all RCTs (100\%), while $70 \%$ of trials reported on the Short Form (36) Health Survey (SF36). Fatigue (FACIT-F) was reported in $29 \%$ of trials with different rates of articles published before and after the OMERACT working group recommendations (27\% vs $50 \%$ ) (1). Data on burden of psoriasis through the Dermatology Life Quality Index in $45 \%$. Other PRO measurements to assess potentially affected health domains such as sleep disturbance, psychological disorders or well-being at work were reported only rarely.

Conclusion: Our SLR shows that all trials report data on HAQ-DI. However important domains as also emphasized by the OMERACT working group (1) are not routinely reported. Especially fatigue, included in 2016 as part of the OMERACT "Inner core" of the PsA Core Domain Set is only reported in about one quarter of studies, although $50 \%$ of studies published after 2016 report on fatigue. Data on emotional well-being, psychological status, productivity losses, and sleep disturbance remain rarely reported in PsA randomized controlled trials. References:

[1] Orbai A, de Wit M, Mease P, et al International patient and physician consensus on a psoriatic arthritis core outcome set for clinical trials. Annals of the Rheumatic Diseases 2017;76:673-680.

Acknowledgments: Acknowledgements: The author BFS had received an economic grant from the Spanish Society of Rheumatology (FER KERN-PHARMA Scholarships for Short stays: Plan for the promotion of research) and the Catalan Society of Rheumatology (BequesNovartis de formació per estades a l'estranger) for the research stay in Vienna (Austria).

Disclosure of Interests: Beatriz Frade-Sosa Grant/research support from: FER KERN-PHARMA Scholarships for Short stays: Plan for the promotion of research. BequesNovartis de formació per estades a l'estranger, Andreas Kerschbaumer Paid instructor for: Celgene, Speakers bureau: Andreas Kerschbaumer has received lecture fees from Bristol-Myers Squibb, Gilead, Merck Sharp and Dohme and Pfizer., Paul Studenic Grant/research support from: Abbvie, Eva Chwala: None declared, Josef S. Smolen Grant/research support from: AbbVie, Eli Lilly, Janssen, Merck Sharp \& Dohme, Pfizer, Roche - grant/research support, Consultant of: AbbVie, Amgen Inc., AstraZeneca, Astro, Celgene Corporation, Celtrion, Eli Lilly, Glaxo, ILTOO, Janssen, Medimmune, Merck Sharp \& Dohme, Novartis, Pfizer, Roche, Samsung, Sanofi, UCB - consultant, Speakers bureau: AbbVie, Amgen Inc., AstraZeneca, Astro, Celgene Corporation, Celtrion, Eli Lilly, Glaxo, ILTOO, Janssen, Medimmune, Merck Sharp \& Dohme, Novartis, Pfizer, Roche, Samsung, Sanofi, UCB - speaker, Daniel Aletaha Grant/research support from: AbbVie, Novartis, Roche, Consultant of: AbbVie, Amgen, Celgene Lilly, Medac, Merck, Novartis, Pfizer, Roche, Sandoz, Sanofi Genzyme, Speakers bureau: AbbVie, Celgene, Lilly, Merck, Novartis, Pfizer, Sanofi Genzyme, UCB DOI: 10.1136/annrheumdis-2020-eular.5967

\section{AB0767 \\ PATIENTS WITH RHEUMATOID ARTHRITIS HAVE A LOWER BONE DENSITY THAN PATIENTS WITH} PSORIATIC ARTHRITIS

D. Freier ${ }^{1}$, E. Wiebe ${ }^{1}$, R. Biesen ${ }^{1}$, T. Buttgereit ${ }^{2}$, S. Hermann ${ }^{1}$, T. Gaber $^{1}$ F. Buttgereit ${ }^{1} .{ }^{1}$ Charité - Universitätsmedizin Berlin, Rheumatology and Clinical Immunology, Berlin, Germany; ${ }^{2}$ Charité - Universitätsmedizin Berlin, Dermatology, Venerology and Allergology, Berlin, Germany

Background: Osteoporosis is a skeletal disease characterized by the loss of bone density resulting in an increased fracture risk. Female sex, advanced age, Caucasian ancestry, previous history of fractures, menopause and certain genetic factors predispose for osteoporosis. In addition, recent studies could prove that chronic inflammatory diseases such as Rheumatoid Arthritis (RA) and long-term treatment with higher doses of glucocorticoids (GCs) represent independent risk factors for the development of osteoporosis. On the other hand, the intake of vitamin $\mathrm{D}$, a calcium-rich diet and physical exercise can be protective. Data describing the prevalence of osteoporosis in patients with other rheumatic diseases like psoriatic arthritis (PsA) are lacking.

Objectives: We compared the prevalence of osteopenia and osteoporosis in patients with RA and PsA, respectively, based on data obtained from our ongoing prospective monocentric study Rh-GIOP investigating glucocorticoid (GC)-induced osteoporosis in patients with different rheumatic diseases (NCT02719314). Methods: Bone mineral density data measured by dual x-ray absorptiometry (DXA) in patients with PsA $(n=92)$ were compared with data measured in 92 age- and 
gender-matched patients with RA. The results were analysed with respect to clinical and laboratory parameters such as data on GC treatment (frequency, duration defined as start of treatment until timepoint of measurement, actual and cumulative dose), csDMARD and bDMARD (including as well tsDMARDs) therapy, serological parameters (Vitamin D, alkaline phosphatase, calcium, inflammatory markers and rheumatoid factor) and functional status (e.g. Health Assessment Questionnaire (HAQ), sporting activities). Statistical analyses were performed descriptively using mean and standard deviation, t-tests for metric variables, and chi-square tests for nominal variables. For subgroup analyses with less than 30 patients per group, tests for non-normally distributed data were used due to the lower test power.

Results: RA patients showed significantly lower means of bone density values (minimal T-score, $p=0.03$ ) than PsA patients leading to a higher frequency of osteopenic bone densities $(p<0.005)$. However, no differences in the frequency of osteoporotic bone densities could be detected. PsA patients reported a significantly longer disease duration and a higher current GC dosage. In contrast, the frequency of current GC intake was higher in RA patients. Although the calcium intake was higher in the RA group, neither blood levels of calcium and vitamin D, nor the cumulative GC dose (GCCD) or duration of GC therapy could indicate a causal relationship for the differences observed in bone density values between the two groups. The frequency of csDMARD therapy did not differ significantly between PsA and RA patients while the frequency of bDMARD therapy was higher in the PsA group $(p=0.04)$.

Conclusion: The lower bone density in RA patients seems not to be fully explained by higher GCCD, disease duration or higher levels of inflammation. However, RA patients had a higher frequency of current GC intake. Additionally, differences in bone density between the two groups could be related to the higher number of bDMARD therapies in PsA patients, but further investigations like multivariate analyses with higher numbers of patients are necessary. Furthermore there is more need for research on possible molecular and genetic factors in PsA, which are protecting from low bone density.

Disclosure of Interests: Desiree Freier: None declared, Edgar Wiebe: None declared, Robert Biesen: None declared, Thomas Buttgereit: None declared, Sandra Hermann: None declared, Timo Gaber: None declared, Frank Buttgereit Grant/research support from: Amgen, BMS, Celgene, Generic Assays, GSK, Hexal, Horizon, Lilly, medac, Mundipharma, Novartis, Pfizer, Roche, and Sanofi. DOI: 10.1136/annrheumdis-2020-eular.3447

\section{AB0768 TREATMENT WITH TOFACITINIB IN REFRACTORY PSORIATIC ARTHRITIS. MULTICENTER STUDY OF 87 PATIENTS IN CLINICAL PRACTICE}

E. Galindez ${ }^{1}$, D. Prieto-Peña ${ }^{2}$, J. L. Martín-Varillas ${ }^{2}$, B. Joven-lbáñez ${ }^{2}$, O. Rusinovich², R. Almodovar ${ }^{2}$, J. J. Alegre-Sancho' ${ }^{2}$, L. Mendez Diaz², A. Sellas-Fernández ${ }^{2}$, À. Martínez-Ferrer², R. Garcia de Vicuna ${ }^{2}$, C. VentínRodríguez $z^{2}$, J. Ramirez ${ }^{2}, M_{\text {. Moreno }}^{2}$, M. J. Moreno², M. D. C. Castro Villegas ${ }^{2}$, A. Crespo Golmar ${ }^{2}$, N. Palmou-Fontana ${ }^{2}$, F. Ortiz Sanjuan ${ }^{2}$, X. E. Larco Rojas' ${ }^{2}$ A. J. Mas $^{2}$, C. Y. Soleto' ${ }^{2}$ I. Gorostiza' ${ }^{1}$, M. A. González-Gay², R. Blanco ${ }^{2} .{ }^{1} \mathrm{HU}$ Basurto, Bilbo, Spain; ${ }^{2} \mathrm{NHS}$, Madrid, Spain

Background: Tofacitinib (TOFA) is the first JAKi approved for psoriatic arthritis (PsA) in Europe (July 2018). TOFA has shown efficacy in refractory patients to antiTNF in Randomized Clinical Trials (RCT) (Gladman D. NEJM 2017; 377: 1525-36). Objectives: To assess efficacy and safety of TOFA in clinical practice (CP). To compare the profile of CP with RCT

Methods: Study of 87 patients of CP with PsA treated with TOFA; Results are expressed as percentage, mean $\pm \mathrm{SD}$ or median [IRQ].

Results: 87 patients $\left(28 \% / 590^{\star}\right)$, mean age of $52.8 \pm 11.4$ years (Table 1$)$. Pattern of joint involvement was: peripheral $(n=60)$, axial (1) and mixed (26). Presented also enthesitis (49.4\%), nail involvement $(30.2 \%)$ and dactylitis (31\%).

Prior TOFA, most patients $(80 \%)$ received oral prednisone, synthetic immunosuppressants (mean 2.3 \pm 0.9$)$ and biological therapy (BT) $(3.6 \pm 1.9)$ : etanercept $(n=58)$, adalimumab (54), infliximab (31), golimumab (37), certolizumab (30), secukinumab (54), ustekinumab (39) and ixekizumab (2). Apremilast was used in 17. After a mean follow-up of $12.3 \pm 9.3$ years from PsA diagnosis, TOFA was started $(5 \mathrm{mg} / 12 \mathrm{~h})$. In $48(55.2 \%)$ TOFA was used in combined therapy: methotrexate (30) and leflunomide (15). In the remaining 39, monotherapy was prescribed.

Patients of CP compared with RCT have a longer duration of PsA, worst functional disability (HAQ) and received a higher proportion of corticosteroids and BT (anti-TNF and non-anti-TNF) (Table 1).

Patients improved in activity indexes (PASI, DAS28, DAPSA) and laboratory test (table 2). Minor side effects were reported in 21 patients (gastrointestinal symptoms), and TOFA was discontinued in 29 due to inefficiency mainly.

Conclusion: Patients of CP had a longer evolution and received a greater number of biologics than those of RCT. TOFA as in RCT seems effective, rapid and relatively safe for refractory PsA.
Table 1. Baseline features

\begin{tabular}{lcc}
\hline & $\begin{array}{c}\text { CLINICAL TRIAL } \\
\text { Gladman } \\
\mathrm{N}=131\end{array}$ & $\begin{array}{c}\text { CLINICAL PRACTICE } \\
\mathrm{N}=87\end{array}$ \\
\hline Age, years (mean $\pm \mathrm{SD})$ & $49.5 \pm 12.3$ & $52.8 \pm 11.4$ \\
Sex, $\mathrm{n}(\%)$ & $67 \mathrm{M} / 64 \mathrm{~F}(51 / 49)$ & $59 \mathrm{M} / 28 \mathrm{~F}(68 / 32.2)$ \\
Duration PsA, years (mean $\pm \mathrm{SD})$ & $9.6 \pm 7.6$ & $12,3 \pm 9.3$ \\
HAQ-DI & $1.3 \pm 0.7$ & $1.4 \pm 0.7(\mathrm{n}=26)$ \\
Swollen joint count, mean $\pm \mathrm{SD}$ & $12.1 \pm 10.6$ & $5.7 \pm 5.8$ \\
Painful joint count, mean $\pm \mathrm{SD}$ & $20.5 \pm 13.0$ & $8.0 \pm 6.6$ \\
Elevated CRP, $\mathrm{n}(\%)$ & $85(65)$ & $55(63.2)$ \\
PASI score, median $[\mathrm{IQR}]$ & $7.6[0.6-32.2]$ & $9.0[4.2-15]$ \\
Oral glucocorticoid, $\mathrm{n}(\%)$ & $37(28)$ & $44(50.5)$ \\
Concomitant synthetic DMARDs, $\mathrm{n}(\%)$ & & \\
- Methotrexate & $98(75)$ & $30(34.4)$ \\
- Leflunomide & $12(9)$ & $15(17.2)$ \\
- Sulfasalazine & $21(16)$ & $6(6.9)$ \\
- Others & $2(2)$ & \\
N. of previous TNF inhibitors, mean $\pm S D$ & $1.7 \pm 1.0$ & $2.4 \pm 1.4$ \\
Previous use of other biological no anti-TNF, $\mathrm{n}(\%)$ & $11(8)$ & $68(78.2)$ \\
\end{tabular}

Table 2. Improvement at $1^{\text {st }}, 6^{\text {th }}$ and $12^{\text {th }}$ month

\begin{tabular}{|c|c|c|c|c|}
\hline & $\begin{array}{c}\text { Baseline } \\
\mathrm{n}=87\end{array}$ & $\begin{array}{l}\text { 1st month } \\
\mathrm{n}=77\end{array}$ & $\begin{array}{c}\text { 6th month } \\
n=52\end{array}$ & $\begin{array}{l}\text { 12th month } \\
n=20\end{array}$ \\
\hline Nail involvement, $\mathrm{n}(\%)$ & $17(19.5)$ & & & \\
\hline Improvement, $\mathrm{n}(\%)$ & & $5(35.7)$ & $6(60)$ & $5(83.3)$ \\
\hline Enthesitis, n (\%) & $28(32.2)$ & & & \\
\hline Improvement, $\mathrm{n}(\%)$ & & $8(47.1)$ & $10(58.8)$ & $3(50)$ \\
\hline Dactylitis, $n(\%)$ & $16(18.4)$ & & & \\
\hline Improvement, $\mathrm{n}(\%)$ & & $9(69.2)$ & $6(85.7)$ & $0(0)$ \\
\hline CRP mg/dl, median [IQR] & $1.9[0.3-5]$ & $0.5[0.1-2.2]$ & $0.5[0.3-1.2]$ & $0.4[0.4-3.7]$ \\
\hline$p$ (vs baseline) & & 0.004 & 0.005 & 0.66 \\
\hline DAS28, median [IQR] & $4.8[4.1-5.40$ & $3.7[2.8-4.6]$ & $2.8[2.2-3.8]$ & $2.9[2.2-3.7]$ \\
\hline$p$ (vs baseline) & & $<0.001$ & $<0.001$ & $<0.001$ \\
\hline DAPSA, median [IQR] & 28 [18.41-34.05] & $15.5[10.1-25.7]$ & $9[6.07-15]$ & $4.3[2.4-8]$ \\
\hline$p$ (vs baseline) & & $<0.001$ & $<0.001$ & $<0.001$ \\
\hline PASI, median [IQR] & $5[1-14]$ & $1.4[0-7]$ & $0[0-4]$ & $0.05[0-2.7]$ \\
\hline$p$ (vs baseline) & & 0.192 & 0.105 & 0.300 \\
\hline
\end{tabular}

Disclosure of Interests: E. Galindez: None declared, D. Prieto-Peña: None declared, José Luis Martín-Varillas Grant/research support from: AbbVie, Pfizer, Janssen and Celgene, Speakers bureau: Pfizer and Lilly, Beatriz Joven-Ibáñez Speakers bureau: Abbvie, Celgene, Janssen, Merck Sharp \& Dohme, Novartis, Pfizer, Olga Rusinovich: None declared, RAQUEL ALMODOVAR Speakers bureau: Abbvie, Celgene, Janssen, Lilly, Novartis, Pfizer.

, Juanjo J Alegre-Sancho Consultant of: UCB, Roche, Sanofi, Boehringer, Celltrion, Paid instructor for: GSK, Speakers bureau: MSD, GSK, Lilly, Sanofi, Roche, UCB, Actelion, Pfizer, Abbvie, Novartis, LARA MENDEZ DIAZ: None declared, Agusti Sellas-Fernández Speakers bureau: Abbott, Lilly, Celgene, Pfizer, Schering-Plough, Janssen, Novartis, and Nordic Pharma, À Martínez-Ferrer: None declared, Rosario Garcia de Vicuna Grant/research support from: BMS, Lilly, MSD, Novartis, Roche, Consultant of: Abbvie, Biogen, BMS, Celltrion, Gebro, Lilly, Mylan, Pfizer, Sandoz, Sanofi, Paid instructor for: Lilly, Speakers bureau: BMS, Lilly, Pfizer, Sandoz, Sanofi, Clara Ventín-Rodríguez: None declared, Julio Ramirez: None declared, Manuel Moreno: None declared, Maria jose Moreno: None declared, María del Carmen Castro Villegas: None declared, Antia Crespo Golmar: None declared, Natalia Palmou-Fontana: None declared, FRANCISCO ORTIZ SANJUAN: None declared, Ximena Elizabeth Larco Rojas: None declared, Antonio Juan Mas: None declared, Christian Y Soleto: None declared, Iñigo Gorostiza: None declared, Miguel A González-Gay Grant/research support from: Pfizer, Abbvie, MSD, Speakers bureau: Pfizer, Abbvie, MSD, Ricardo Blanco Grant/research support from: AbbVie, MSD, and Roche, Speakers bureau: AbbVie, Pfizer, Roche, Bristol-Myers, Janssen, and MSD DOI: 10.1136/annrheumdis-2020-eular.2903

\section{AB0769 THE IMPACT OF BODY MASS INDEX ON DISEASE ACTIVITY AND ENTHESITIS IN PSORIATIC ARTHRITIS}

S. Ganhão ${ }^{1}$, B. M. Fernandes ${ }^{1}$, S. Garcia ${ }^{1}$, F. Pinheiro ${ }^{1}$, M. Rato ${ }^{1}$, E. Mariz ${ }^{1}$, M. Bernardes ${ }^{1,2}$, L. Costa ${ }^{1}{ }^{1}$ Centro Hospitalar e Universitário de São João, Rheumatology, Oporto, Portugal; ' ${ }^{2}$ Faculty of Medicine of Oporto's University, Oporto, Portugal

Background: Overweight/obesity has increased exponentially in the last decades, becoming a huge Public Health problem. Moreover, an increase in adipose tissue is associated with an increased production of several proinflammatory cytokines and acute phase reactants. Higher BMI has been related with new bone formation including syndesmophytes and enthesophytes. In fact, besides 